\title{
LEVERS OF STATE REGULATION OF STRUCTURAL CHANGES IN THE NATIONAL ECONOMY
}

\section{Key words:}

structural changes; national economy; state regulation; tools of regulation; system of management.

\section{Nazarkevych I.B.}

Ivan Franko National University of Lviv

Ukraine, 79001, Lviv, Svobody ave., 18

nazigor22@gmail.com

ORCID 0000-0001-5856-531X

The article is devoted to the research of problems of formation and implementation of mechanisms, methods and measures of state regulation of structural transformations of the national economy. The interpretation of mechanisms, methods, tools and means of state regulation of the economy in domestic economics is studied. It is substantiated that the main shortcomings of the application of the program-target method of national economy management are chronic underfunding of state and local target programs, weak involvement of stakeholders and ineffective control over the implementation of programs and projects. It has been analyzed the European experience of the state practice of coordinating structural changes in accordance with the priorities of socio-economic development, in particular the application of such a regulatory tool as tax benefits. It is proved the expediency of using a reactive and proactive system of public administration in achieving the strategic goals of the national economy, which will more optimally determine the necessary means for their implementation, as well as prevent and respond to negative socio-economic effects. The measures of public administration within the mechanism of state regulation of structural changes in national economy are systematized. The basic tools of state regulation of structural reform of the national economy with grouping by mechanisms, tools and features of their application are determined. It is noted that the applied methods and tools of state regulation may stimulate and / or limit effects on different groups of stakeholders. It is investigated that the tools of state influence on economic processes are constantly expanding, including through digital technologies, and can have a significant difference in performance depending on the scope, level of relations, strategic goals and operational objectives.

\section{ВАЖЕЛІ ДЕРЖАВНОГО РЕГУЛЮВАННЯ СТРУКТУРНИХ ЗМІН В НАЦІОНАЛЬНІЙ ЕКОНОМЦЦ}

\section{Назаркевич I. Б.}

Львівський національний університет ім. І. Франка Україна, 79001, м. Львів, пр. Свободи, 18

\section{Ключові слова:}

структурні зміни; національна економіка; державне регулювання; засоби регулювання; система управління.
Стаття присвячена дослідженню проблем формування та імплементації механізмів, методів та заходів державного регулювання структурних трансформацій національної економіки. Досліджено трактування механізмів, методів, інструментів i засобів державного регулювання економіки у вітчизняній економічній науці. Обгрунтовано, що основними недоліками застосування програмно-цільового методу управління національної економіки $€$ хронічне недофінансування державних і місцевих цільових програм, слабке залучення стейкхолдерів та неефективний контроль за виконанням програм $\mathrm{i}$ проектів. Проаналізовано європейський досвід державної практики координування структурних змін відповідно до пріоритетів соціальноекономічного розвитку, зокрема застосування такого інструменту регулювання як податкові пільги. Наведено доцільність застосування реактивної i проактивної системи державного управління в досягненні стратегічних цілей розвитку національної економіки, що дозволить більш оптимально визначати необхідні засоби для їх реалізації, а також запобігати та оперативно реагувати на виникнення негативних соціально-економічних ефектів. Систематизовано заходи публічного управління в рамках механізму державного регулювання структурних змін національної економіки. Визначено базові засоби державного регулювання структурного реформування національної економіки 3 групуванням за механізмами, інструментами та особливостями їх застосування. Зазначено, що застосовані методи та інструменти державного регулювання можуть мати стимулюючий та/або обмежуючий ефекти для різних груп стейкхолдерів. Досліджено, що інструментарій державного впливу на господарські процеси постійно розширюється, в тому числі завдяки цифровим технологіям, а також може мати істотну відмінність в результативності залежно від сфери, рівня відносин, стратегічних цілей і оперативних завдань. 


\section{Statement of the problem}

The main problems produced by the classical market model of the economy are the deepening of differentiation in the material well-being of the population and the low level of social mobility. The eternal problem is that the balance between the capitalist and the employee remains the cornerstone today. The dynamic development of Germany and Japan, countries that lost World War II, has shown that the success of these countries largely depends on this balance. And the main role in ensuring this balance is assigned to the system of state regulation of the national economy.

Another factor in the development of the state is the control over the movement of capital, which to some extent contradicts liberal economic theories, but the experience of China and "The Asian Tigers" in general shows that such measures are critical to sustainable development. However, this issue is relevant today not only to Asian countries. At the level of the EU and the World Bank, the issues of financial flow control are actively discussed, especially in offshore zones in order to prevent money laundering.

In the era of digitalization, intensification of cybercrime, growth of financial markets, in particular cryptocurrencies, control over these processes is weakening. However, the development of digital technologies allows to expand the list of methods and tools of state regulation to provide positive structural changes in the national economy.

There is an inertial nature of economic development including through the inheritance of certain processes from the USSR and low innovation activity in Ukraine. This feature requires the implementation of qualitative structural changes and the formation of an effective system of state regulation of the national economy.

\section{Analysis of recent studies and publications}

It is worth to note Bezguba M. [1], Bila I. [2], Ermolenko O. [4], Zakharchenko V. [5], Komarnytsky I. [6], Saniakhmetova N. [9], Shabanov R. [11] and others among national scientists who have studied the formation and implementation of levers of state regulation in the national economy transformation.

\section{Objectives of the article}

The objective of the study is to determine the methods and tools of state regulation aimed at ensuring effective structural reform of the national economy.

\section{The main material of the research}

According to Ermolenko O., the instruments of state regulation are the mechanisms and institutions through which the national economy conducts regulatory activities aimed at the development of the industry, as well as the allocation of resources and the formation of proportions, based on macroeconomic analysis of the industry [4, p. 10]. Although the author makes his interpretation in relation to the energy sector, this statement is debatable. In our opinion, mechanisms in economics are a broader concept than tools and, accordingly, should not be considered as components.

According to R. Shabanov and M. Zhdan, the basis of state regulation of the national economy is the tools of legal regulation of economic activity and methods of state influence on the economy. Means of legal regulation of economic activity is a purely theoretical concept used to defend the sectoral specifics of economic law. In turn, the method of state influence on the economy has a purely practical meaning, as it allows to develop the content of state economic policy for the purposes of further legal consolidation. Methods of state influence on the economy consist of a set of means of regulation. Thus, the method of legalization of economic activity includes such means as registration of economic entities, licensing, obtaining permits, and the method of monetary regulation - regulation of prices and tariffs, accounting policies, setting standards for capitalization and capitalization of funds of economic entities and others. [11, p.85].

The system of means and tools of state regulation of the economy includes the following groups [1, p.160]:

- means of state regulation: economic (taxes, duties and fees, public investment and subsidies, subventions, grants, loans and borrowings, monetary instruments; government orders and procurement, prices for agricultural products); administrative (standards, regulations, permits, prohibitions, restrictions, limits, fines); information (publications in the media, documents).

- instruments of state regulation: legislative and legal (laws, resolutions, decrees); normative-administrative (orders, decisions, instructions, orders, instructions, rules, regulations, agreements); organizational and economic (plans, projects, state and local budgets, state order and state contract, contracts, target programs, forecasts).

Priorities and mechanisms of socio-economic development of European society for the near future are defined in the EU strategy "Europe-2020". Its structural components include intellectual growth (smart growth), based on investment in education, research and innovation; sustainable growth on the basis of efficient and appropriate use of natural resources; inclusive growth which aims to reduce poverty, ensure maximum employment, achieve social and territorial cohesion. The main institutional mechanisms for implementing the strategy are as follows [10, p.214].

The country's economic policy was supplemented by such levers of regulation as: state guarantees and loans, investment incentives and tax benefits after Belgium's accession to the EU. Then the system of state planning of economic development began to be applied. In Italy, the state assigns an important role to the regulation of enterprises in which it has a direct or indirect control interest. It affects a wide range of economic activities and in particular banking, transport, communications, energy, engineering, uses public investment and assistance programs [9, p.101].

The program-targeted method of management is an important tool for state regulation of structural changes in the national economy. Strategies for the development of 
spheres and branches of the national economy can be considered as a weak point of state regulation of structural changes in Ukraine. Despite the fact that there were many programs for the development of certain industries during the years of independence, their formation and, most importantly, implementation left more questions than answers.

First of all, it is worth paying attention to the chronic underfunding of most programs, especially in the medium term. As funding for short-term programs was practically pledged in the current budget year, this did not cause any problems, and there were almost no longterm programs.

Another problem is the frequent inconsistency of sectoral programs with the overall strategy of socio-economic development of the country. This inconsistency was expressed in dissonance regarding the goals, tools for achieving them, measures to coordinate deviations, and so on. For example, in the development strategy the main emphasis of the development of the industry is aimed at increasing labor productivity, and directly in the target program - to increase employment. Which, accordingly, violated the structure of the relationship between the achievement of goals.

An equally important problem was the complete absence or weak involvement of stakeholders in the development and implementation of program-targeted tools for the industries' development. As a result, this approach undermined the interests of key agents for the development of sectors and industries and did not improve the investment environment.

Tax policy plays an important role in the issue of state regulation of structural transformations. In the UK, for example, individual firms are not required to register with the state, and taxes are paid on the basis of declaring the individual income of the firm's members. And even if the firm is registered with the government, taxes are paid only after the firm has become active in the market and found its customers. In general, the amount and taxes paid by small enterprises are smaller and the taxation procedure is much simpler than for large enterprises. In addition, progressive corporate income taxation is also used: tax rates for lower-income corporations are lower than for high-income corporations [6, pp.53-54].

In general, tax benefits are one of the most common mechanisms of state regulation, including structural change, in the national economy. For example, in Poland, to stimulate the development of small business, the state provides assistance to newly established enterprises in the amount of 16 thousand zlotys, as well as the payment of only half of the single social contribution rate during the first year of operation.

In France, small businesses do not file value added tax returns, but pay income taxes, the level of which depends on the field of activity (trade, services, etc.) [7, p.228]. In addition, there are benefits for newly formed joint stock companies (during the first two years - no tax is paid, in the third year $25 \%$ of their profits are taxed, in the fourth - $50 \%$, in the fifth $-75 \%$, starting from the sixth year $100 \%$ of profits), the tax credit is applied also for the enterprises which are carrying out professional training, etc. [5, p.67].

The state regulates changes in the structure of production, affects the sale of social product, the rate of capital accumulation and technical renewal of production capacity of the state, preventing the growth of the budget deficit, and regulates inflation, stabilizes the state and balances the budget by using certain tax benefits [8, p.63].

It is possible to assert that the objective function of prognostication, planning and programming of socioeconomic development of country, is the grounded prediction of directions of development of country, separate industries of economy, possible state of economy and social sphere, in the future, and also alternative ways and terms of achievement of parameters of economic and social development while characterizing the basic elements of the system of government control of enterprise. The second element of the system of state regulation of entrepreneurship is antitrust and competition policy aimed at preventing monopoly activities, restricting and terminating them, and developing civilized competitive relations between entities. The antitrust policy of the state includes two main areas: demonopolization and regulation of monopolies. Competition policy is aimed at creating and protecting a competitive environment. Tax and investment policy, as an element of the system of state regulation of entrepreneurship, are activities of the state aimed at creating conditions for the functioning of entrepreneurship through the use of tax levers, monetary and financial regulation to stimulate or restrain the development of national production. Innovation policy and R\&D incentives are aimed at the development and dissemination of basic and applied research, improving the infrastructure of industries and individual regions. The mechanism of creation and dissemination of innovations has three common components, characteristic of almost all countries: the system of state support for basic and exploratory research; various forms and sources of funding and indirect stimulation of research and support of small innovative entrepreneurship [2, p.29].

One of the key components of state regulation is the financial mechanism. M. Bezguba considers the financial mechanism as an integral part of the economic mechanism, which is a set of financial incentives, levers, tools, forms, and methods of regulating economic processes and relations. The main purpose of financial regulation is to ensure economic and social stability by creating appropriate conditions for balanced economic growth [1, p.160]. The financial mechanism, as well as the mechanism of state regulation of structural changes in the national economy includes three groups of measures: economic, legal and organizational (see Fig. 1). 


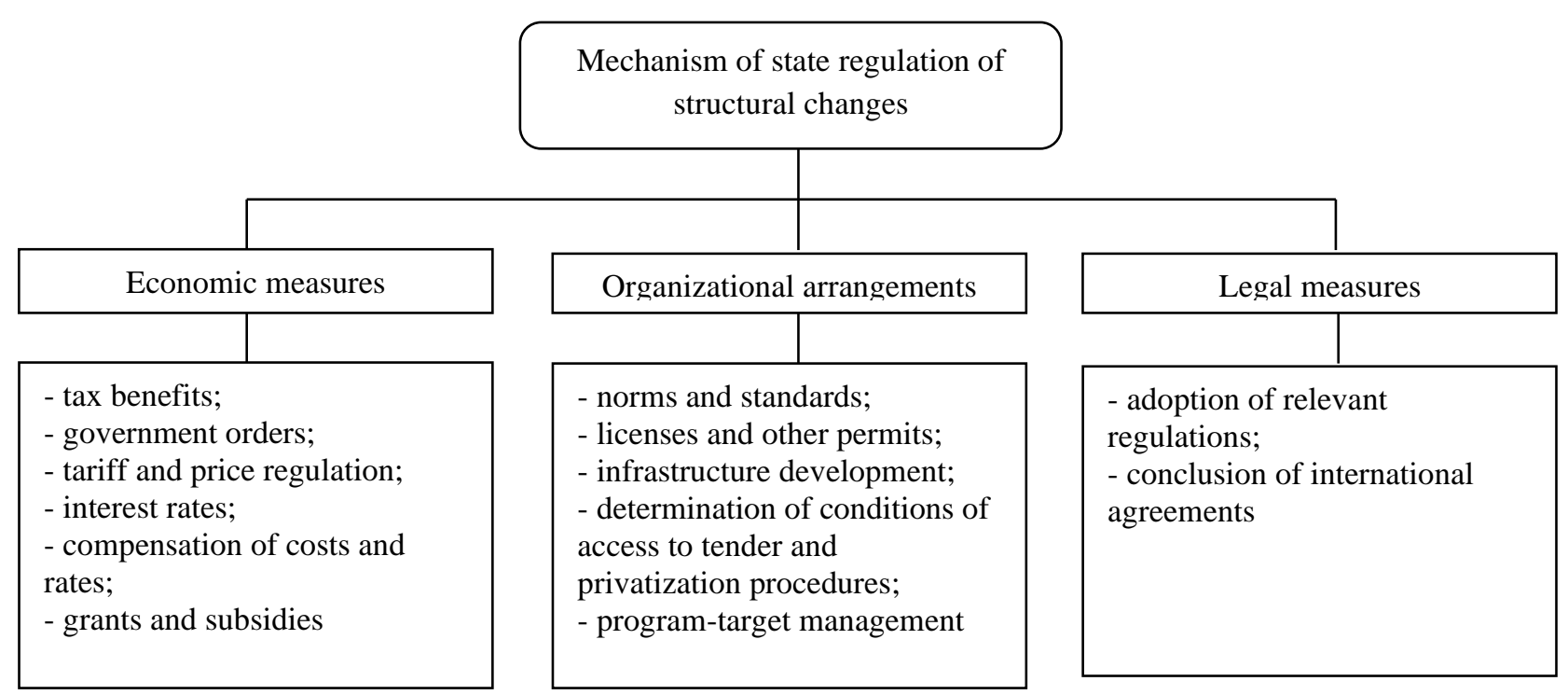

Figure 1. The mechanism of state regulation of structural changes in the national economy [own work].

At the same time, economic measures should be understood as the purposeful use of instruments to influence the system of public relations, which determines the financial and economic motivation, interests and behavior of the subjects of financial policy of the state. Legal measures should include the legalization of the process of formation, implementation and control over the effectiveness of public financial policy in the form of a system of regulations governing the functioning of the relevant relations between financial policy entities within the economic system in which the domestic financial system is integrated. Organizational measures cover the activities of state financial and economic institutions that are directly involved in the development, implementation and control of financial policy of the country [1, pp.160-161].

The same groups of measures of state regulation can be extrapolated to the structural reform of the national economy, but with broader management tools.

Article 12 of the Economic Code of Ukraine defines the main tools of regulatory influence of the state on the activities of economic entities, in particular: the state order; licensing, patenting and quotas; technical regulation; application of standards and limits; regulation of prices and tariffs; providing investment, tax and other benefits; providing grants, compensations, targeted innovations and subsidies [3]. However, despite the rather short list of tools specified in the Code, the system of state regulation of the economy has a wide range of tools to influence economic processes, which can vary significantly depending on the scope, level of relations and strategic goals and operational objectives.

The chosen type of management system is also important in the issue of the structural transformation of the national economy. Today, the most effective are jet and proactive control systems. The key goal of reactive control is to organize a system of timely response to errors and deviations and prevent their recurrence. The purpose of the proactive system is to implement preventive measures to prevent adverse effects.

Depending on the type of functioning management system of the national economy, methods and tools of state regulation can be used, which will have stimulating or limiting effects. However, in many cases, the application of one or another instrument of state regulation may have a stimulating effect for some business entities and a restrictive one for others. For example, setting customs tariffs or quotas on certain groups of imported goods will have a restrictive effect on importers, but will stimulate the revitalization of domestic producers.

It should be noted that the regulation of the economy through the application of rules provided by the implementation of sanctions is an important way an economical regulation in contrast to other elements of state influence on the economy. The government regulation is mostly not based on economic intentions to achieve the goal. Other instruments of state influence on the economy (taxation, subsidies) are aimed at changes in the activities of entities through the use of economic incentives or the use of other methods (e.g., dissemination of information by government agencies that affects behavior in the economy) [11, p.85]. In general, the instruments of state regulation are components of broader means of public administration, namely mechanisms. Actually, the mechanisms of state regulation are a set of methods and tools of state influence on the processes of structural transformation of the national economy (see Table 1).

This approach allows to structure the system of levers of state regulation more clearly. Also, it is designed to promote more effective use of these tools in the strategic and operational management of the national economy. 
Table 1 Means of state regulation of structural changes in the national economy

\begin{tabular}{|c|c|c|}
\hline Mechanisms & Tools & Features of application \\
\hline Monetary & $\begin{array}{l}\text { - lending (including preferential, compensation of } \\
\text { credit rates); } \\
\text { - monetary instruments (discount rate, } \\
\text { provisioning rates, securities transactions, money } \\
\text { issue, exchange rate regulation) }\end{array}$ & $\begin{array}{l}\text { used in the monetary regulation of the money } \\
\text { supply in the national economy, capital } \\
\text { market development }\end{array}$ \\
\hline Price & $\begin{array}{l}\text { - antitrust regulation; } \\
\text { - establishment of state and communal prices; } \\
\text { - pricing conditions }\end{array}$ & $\begin{array}{l}\text { aimed at stabilizing prices, compliance with } \\
\text { market competition }\end{array}$ \\
\hline Fiscal & $\begin{array}{l}\text { - tax regulation; } \\
\text { - customs regulation; } \\
\text { - budget regulation (interest deductions from } \\
\text { territorial revenues, budget transfers) }\end{array}$ & $\begin{array}{l}\text { used for redistribution of GDP, financial } \\
\text { support for the functioning of state } \\
\text { institutions, social standards, infrastructure } \\
\text { development, etc. }\end{array}$ \\
\hline Program-target & $\begin{array}{l}\text { - indicative planning; } \\
\text { - development and implementation of strategies, } \\
\text { programs, projects; } \\
\text { - state order within the framework of state programs }\end{array}$ & $\begin{array}{l}\text { provides for the implementation of planning, } \\
\text { forecasting and implementation of socio- } \\
\text { economic development programs in } \\
\text { accordance with the defined objectives, } \\
\text { deadlines, methods and tools }\end{array}$ \\
\hline $\begin{array}{l}\text { Administrative and } \\
\text { legal }\end{array}$ & $\begin{array}{l}\text { - regulations; } \\
\text { - permit system and licensing (standardization, } \\
\text { certification, patenting, quotas) }\end{array}$ & $\begin{array}{l}\text { determines the legal boundaries of socio- } \\
\text { economic relations }\end{array}$ \\
\hline
\end{tabular}

Source: [own work].

\section{Conclusions}

In conclusion, it should be noted that the formation of an effective system of state, regulation of structural changes in the national economy requires the development and implementation of effective levers for managing socioeconomic processes. The application of a reactive and proactive management system in achieving the strategic goals of the national economy will allow to more optimally determine the necessary tools for their implementation. Thus, it will contribute to the improvement of the integrated system of state regulation of structural reform of the Ukrainian economy and the formation of an effective structural policy.

\section{References}

1. Bezguba, M.O. (2016). Finansovyi mekhanizm derzhavnoho rehuliuvannia ekonomiky [Financial mechanism of state regulation of the economy]. Economic Bulletin of the University. (Vols. № 28/1). (pp. 158-165). [in Ukrainian].

2. Bila, I.S. \& Salatiuk, N.M. (2014). Svitovyi dosvid derzhavnoho rehuliuvannia pidpryiemnytstva [World experience of state regulation of entrepreneurship]. Problems of economy № 1, (pp. 26-30). [in Ukrainian].

3. Hospodarskyi kodeks Ukrainy [Economic Code of Ukraine]. // Bulletin of the Verkhovna Rada of Ukraine. (2003). [in Ukrainian].

4. Ermolenko, O. (2013). Osnovni instrumenty derzhavnoho rehuliuvannia v enerhetychnii haluzi Ukrainy [Basic tools of state regulation in the energy sector of Ukraine]. Scientific Bulletin of ChDIEU. № 3 (19). (pp. 9-15). [in Ukrainian].

5. Zakharchenko, V.I., Borisov, O.G. \& Ivanishcheva, A.V. (2005). Zarubizhnyi i vitchyznianyi dosvid derzhavnoho rehuliuvannia ekonomiky dlia suchasnoi Ukrainy [Foreign and domestic experience of state regulation of the economy for modern Ukraine]. Odessa: Publishing Center Studio "Nigotsiant". [in Ukrainian].

6. Komarnytsky, I.M. (2000). Orhanizatsiino-ekonomichni mekhanizmy rozvytku pidpryiemnytstva [Organizational and economic mechanisms of business development]. Uzhhorod: Publishing House "Patent". [in Ukrainian].

7. Lekh, G.A., Ilchyshyn, M.M. \& Turkalo O. Ya. (2011). Svitovyi dosvid rozvytku pidpryiemstv maloho biznesu [World experience of small business development]. Scientific herald of NLTU of Ukraine: (Vols. 21.15). Collection of scientific and technical works. (pp. 224-229). [in Ukrainian].

8. Pidlisna, O. (2002). Podatkovi pilhy - instrument derzhavnoho rehuliuvannia ekonomiky [Tax benefits - an instrument of state regulation of the economy]. Bulletin of the Tax Service of Ukraine. № 9. (pp. 62-64). [in Ukrainian].

9. Saniakhmetova, N.A. (1998). Regulirovanie predprinimatelskoj deyatelnosti v Ukraine: organizatsyonno-pravovyje aspekty [Regulation of entrepreneurial activity in Ukraine: organizational and legal aspects]. Odessa: [b.v.]. [in Russian].

10. Suprun, N.A. (2015). Korporatyvna sotsialna vidpovidalnist yak mekhanizm zabezpechennia intehratsii Ukrainy v YeS na pryntsypakh staloho rozvytku [Corporate social responsibility as a mechanism for ensuring the integration of Ukraine into the EU on the principles of sustainable development]. Paradigmatic shifts in the economic theory of the XXI century. Kyiv: (pp. 214-217). [in Ukrainian].

11. Shabanov, R. \& Zhdan, M. (2016). Shchodo poniattia hospodarsko-pravovykh zasobiv derzhavnoho rehuliuvannia ekonomiky za zakonodavstvom Ukrainy [On the concept of economic and legal means of state regulation of the economy under the laws of Ukraine]. Entrepreneurship, economy and law. №11., (pp. 84-88). [in Ukrainian]. 